\title{
oopoe in Ancient Egypt
}

\section{Introduction}

Dr. Mofida elweshahy

The unique geographical position of Egypt acting as a bridge between the continents is the reason of why so many migrating birds are concentrated and stopped over Egypt, Birds' bones were found at the site of Wadi Shoaath near Gebel el Silsila (17.00012000BC.) in the site E.71 K.20, ${ }^{1}$ birds form where known in slate palettes, on pottery ${ }^{2}$, ivory combs and pins $^{3}$ and flint in the form of a bird or flying bird. ${ }^{4}$ The northern Delta' Lakes act as a major refuge for many species of bird from the $2^{\text {nd }}$ Dynasty ${ }^{5}$ onwards. ${ }^{6}$ Several species of birds can be identified ,they were $73^{7}$,in Sir A. Gardiner' sign lists were 62 sixty- two standard hieroglyphics depicted birds and parts of birds, including the hoopoe.$^{8}$

Hoopoe upupa epopas is a very cernmen resident breeding bird and passage- migrant, it found on farmland, fields and gardens, it

\footnotetext{
-Suez Canal University Faculty of Tourism.

${ }^{1}$ Patrick . F. Haulihan, The Animal World of The Pharaohs (Cairo, 1996) , 134 ; P.StrauB, “ Vogel”, LA VI (1986) , 1046 ; Springerlink- metapress.com . proceeding plant sciences vol.68 , (1969), Amatory of the feeding AppA- ratus of hoopoe ;

بياتركس ميدان ، رينيس ، عصور ما قبل التاريخ فى مصر من المصريبين الأو ائل إلى الفر اعنة

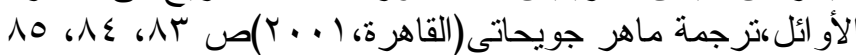

${ }^{2}$ W. M. F. Petrie, Corpus of Prehistoric Pottery and Palettes, BSAE (London, 1921), pl.LIIL , 20 ; J.Vandier, Manuel d'Archeologie Egyptienne, Le époques de formation ( Paris , 1952), 306, 352 ; Petrie Corpus of Prehistoric Pottery , pl. XXXV- D. 50- 66 ;

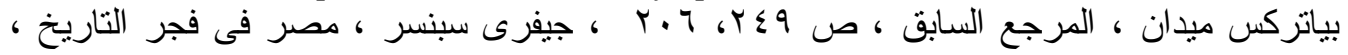

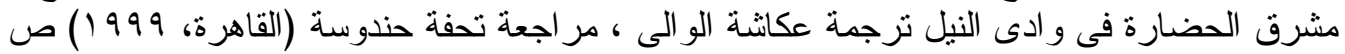

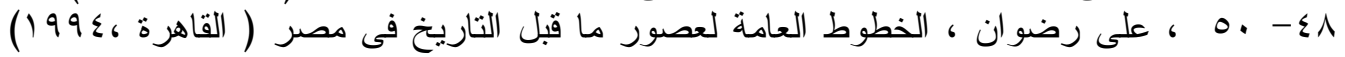

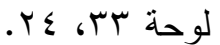

${ }^{3}$ W.F.Petrie, J.Qwible, Naqada and Ballas ,( London, 1895), pl.LXIII .

${ }^{4}$ M.Elweshahy, Flint in The form of Animals in Prehistoric Egypt, Association of Arab Universities For Tourism and Hospitality, Ismailia , 20071 , p. 87, figs. 32- 38 .

${ }^{5}$ B.Bruun, Common Birds of Egypt (Cairo, 1985), 2 , 20 .

${ }^{6}$ B.Bruun, Ibid (1985), 34 ; F.Houlihan, Ibid (1996), 112- 139).

${ }^{7}$ P.F.Haulihan, Animal World , p. 112 .

${ }^{8}$ A.Gardiner, Egyptian Grammer (Oxford , 1973), G.38 , 39 , 40 , 41 ; LD, III, 56-A .
} 
raises its larg crest when excited and lives on insects and warms . Phonatic is $D b$ in $, D b t,{ }^{10}$ it gives the meaning a brick La' in the pyramid Text 240 as follow : “O you expectoration of a wall, you vont of a brick, what comes of your mouth is turned back against yourself " . ${ }^{11}$

The Hoopoe sign gives also the meaning of $D b t$ nt inb tom

a birk in a wall, ${ }^{12}$ staff, forming of the brick in $D b t{ }^{13}$ and 命䒢

a shrine in Dbt $\quad .{ }^{14}$ Hoopoe appeared as a Hieratic sing in ancient Egyptian papyri . It appeared in the papyri of EBers

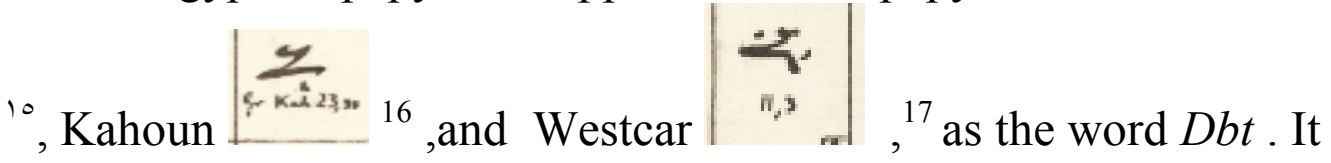

${ }^{9}$ B.Bruun, Common Birds , p. 34 , (4 : 22), pl. 10 ; Gardiner, Egyptian Grammar , p. 469.

${ }^{10} \mathrm{~Wb}, \mathrm{VI}, 553,554$.

${ }^{11}$ R. O. Faulkner, The Ancient Egyptian Pyramid Texts (2007), p. 37 , Utterance 241, 246.

${ }^{12} \mathrm{~Wb}, \mathrm{~V}, 554 / 4$.

${ }^{13} \mathrm{~Wb}, \mathrm{~V}, 554 / 18$.

${ }^{14} \mathrm{~Wb}, \mathrm{~V}, 554$, gr .

15 - W.Wreszinski , The Text of Papyrus Ebers (Leipzig , 1913) , 47 (246) , 93 (276);

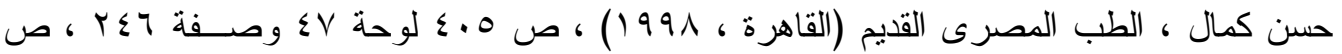

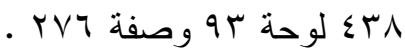

${ }^{16}$ F. L. Griffith , Hieratic papyri from Kahun \& Gurab , (1898) , (5- 11), (23- 11) .

${ }^{17}$ Papyrus of Westcar , 11,3 . 
used also as a letter $D b^{18}$ or 19 and appeared in Koptic TWBE- TWBI

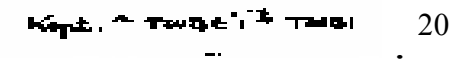

Swamp hunts were first and foremast an highly valued by the mobility through all periods of Egyptian history, it consists of two elements- fish spearing and bird hunting with throwing stick . ${ }^{21}$ The king himself was the royal hunter to defeat his enemies (of Egypt and the underworld). So every deceased person was now portrayed himself as a royal activities and to defend himself in the beyond against the dangers that threatened him in the under world. The scene magically was also the rebirth of the deceased, a social event and an erotic scene . ${ }^{22}$ The researcher suggests that the swamp hunts' scene represented the lake of bird and fish as seen in the coffin Text, spells 34 ix di-i m33 r- $i$ sxt Xrj 3pdw (3pdw$r m w)$ : I will cause (you) to see for me (the king) the field of birds (birds and fish).

In the Tombs of $6^{\text {th }}$ Dynasties at Saqqara, daily life scenes were represented and Tombs of the Nobles at Middle and Upper Egypt, ${ }^{24}$ specially the swamp hunt scenes which depicted Hoopoe in ancient Egypt as seen in these documents .Hoopoe was kept for pleasure in ancient Egypt, several wall- appointed tombs dating from the early time of the $4^{\text {th }}$ Dynasty, Children of both sexes regularly appear on tomb- chapel walls standing naked close to their

\footnotetext{
${ }^{18}$ Valeurs phonetiques des signes Hieroglyphiques d' Epoque Greco- Romaine (Montpellier , 1988), 343/1401, p. 87 .

${ }^{19}$ - Ibid , 845/1402, p. 87 ; Wb , V , 561 .

${ }^{20} \mathrm{~Wb}, \mathrm{~V}, 553$.

${ }^{21}$ W.Decker, Sports and Games of Ancient Egypt, translated by A.Guttmans (1992) , p. 158 . (figs. 123, 126 ; LD III , 56- A .

22 W.Decker, Sports and Games, p. 159,160 .

${ }^{23}$ O.R ,Faulkner, The Ancient Egyptian Coffin Texts spell 34 ; De Buck, The Egyptian Coffin Texts I (1935) , 124 ; M.Elweshahy, Lakes of Purification in Ancient Egyptian Afterlife ,

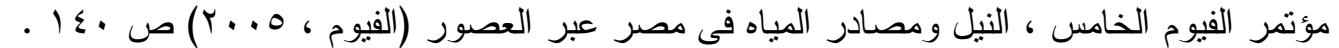
${ }^{24}$ Z- Hawas, The Treasures of The Pyramids (2010) , p. 286- 327 .
} 
parents' side, they clutch a colorful pert Hoopoe ${ }^{25}$ appeared in the fish spearing (fishing) and the swamp hunt (fowling), it was social event in which women and children' participated ${ }^{26}$, as seen in these figures :

\section{I- Hoopoe in The Old Kingdom :}

Doc.1: The Mastaba of Queen Mersy- Ankh III.(G. 7530,7540 ) $4^{\text {th }}$ Dyn.The scene depicted, the king's beloved wife Mersy- Ankh III is standing with her mother queen Hetphers II and in front of her feet a marked boy is walking to the left with face turn right, he wears a side- lock.In the right hand he grasps a hoopoe by its wings over his head his name is written" Khenterka " $x n t-r-k 3$ (fig .1).$^{27}$ Doc.2 : The Mastaba of Queen Mersy- Ankh III- Giba- $4^{\text {th }}$ Dyn . The scene depicted the prince Neb- $m-a k h t$ as a man walking to the left , behind him three children all facing left nom inscribed, in the center is a naked girl carrying a hoopoe held by the wings in her right hand (fig . 2).$^{28}$

Doc.3 : The Temple of king Weserkaf at Saqqara $.5^{\text {th }}$ Dyn. Cairo Museum- limestone. A scene from court the funerary temple of king Weserkaf at Saqqara was depicted in a fine relief's of the spearing fish and hunting of birds with throwing- stick in a papyrus marsh, it is full of beautifully drown birds among them was a hoopoe standing on a papyrus facing left . (fig.3).$^{29}$

Doc. 4 : The Temple of king Weserkaf at Saqqara $5^{\text {th }}$ Dyn., Cairo Museum . The limestone scene represented the life of the king

${ }^{25}$ D. Walfgang, Sports and Games, p. 160 .

${ }^{26}$ Holihan, The Animal World , p. 112 ; E. Feucht , "Kind “, LA III (1980), 427 ;

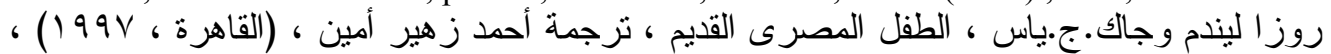

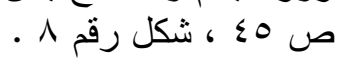

${ }^{27}$ A.Hassan,The Queens of The Fourth Dynasty(Cairo,1997),p. 20 ; D.Dunhan, W. K. Simpson , The Mastaba of Queen Merey-Aankh III (Buston, 1974), pl. VII , p. 14 (main roon- w.w) .

${ }^{28}$ Ibid, pl. VII , p. 14 , fig . 7.

${ }^{29}$.S.Smith, The Art and Archtecture of Ancient Egypt (1990), fig . 119 , p. 127 ; Z.Hawas, The Treasures of The Pyramids (Cairo , 2010), p. 237 ; J.P.Corteggiani , Egyptian Museum (1987) , No. 19 , p. 50 ; M.Saleh, H.Sourouzian, The Egyptian Museum (Cairo , 1987), No. 36. 
Weserkaf as a private man, it depicted a net which had been thrown over one of the trees to catch small birds, other birds hover in the air above the trees, the Hoopoe is one of them (fig. 4).$^{30}$

Doc. 5 : The Tomb- chapel of Niankhkhnum and Khnumhotep at Saqqara $5^{\text {th }}$ Dyn. . The lowing scene of this Tomb-chapel, depicted the deceased with his beloved wife Khentkaws, hunt in the swamp which filled birds, he took the roll of the king in afterlife. The grave her as a site of eternal life, every deceased person was now allowed to portray himself at the royal activities, here the deceased folds a hoopoe and another small bird in his right hand, while the text above him gives the hoopoe as a determinative for word $3 b d w$ (bird), its reads : ..... bHs $3 b d \ldots . m p H w \quad \ldots . n H t \quad$ " throw stick.... the bird ... in the marsh- land .... of the Delta . and there is a Hoopoe hover his wings on the the papyri swamp (fig.5) ${ }^{31}$.

Doc .6 : The Tomb- chapel of Niankhknum and Khnumhotep at Saqqara $5^{\text {th }}$ Dyn. . The fishing scene of the Tomb- chapel depicted the Hoopoe hovers on the swamp and also another Hoopoe stands on the papyrus (fig.6) . ${ }^{32}$

Doc. 7 : The Mastaba of Ptahhotep at Saqqara $5^{\text {th }}$ Dyn. . In the fishing scene, the deceased Akht-Hotep with his elder son Ptahhotep were watching the products of fields and the fishing, the boy was represented stand facing left and holding a Hoopoe by wings (fig.7).$^{33}$

Doc. 8 : The Mastaba of Ptahhotep at Saqqara, $5^{\text {th }}$ Dyn. . Scene from this Mastaba represented two Hoopoes hover above the papyri on the swamp . (fig. 8 ) . ${ }^{34}$

Doc .9: The Tomb of Neferseshame and Seankhuto at Saqqara $6^{\text {th }}$ Dyn. . The scene of the tomb represented the tomb owner

${ }^{30}$ Smith , Art and Architecture, p. 127,128 , fig . 120 ; LD, II .55 .

${ }^{31}$ A. M. Moussa , H. Altenmiller, Das Grab des Nianch Chnum und Chnumhotep (Mainz , 1977), Abb.6, SZ.4. (302) .

${ }^{32}$ Maussa, Altenmuller, Nianchchnum, Abb.5 , SZ.4. (301) .

${ }^{33}$ N.de G.Davies, The Mastaba of Ptahhotep and Akhethotep at Saqqara ,Part II (London , 1901), pl.III

${ }^{34}$ Davies, Ptahhotep, Part II , pl. IV . 
participating in fishing and fowling with good ability of sculptor and much more of the painter. In the center of the scene is a papyrus thicket, two rows of birds, the first one of the upper row is a hoopoe and the $3^{\text {rd }}$ and last one in the $2^{\text {nd }}$ row are hoopoes, the text reads :xns $S s w$ pHw "fare throw marshland (fig.9). ${ }^{35}$

Doc . 10 : A fishing scene from the tomb of Seankhuptah room Ieast wall shows the hoopoe nests on the papyrus, it protects its baby or eggs . (fig . 10,11$).^{36}$

Doc . 11 : A scene from the Mastaba of Nikauisesi , $6^{\text {th }}$ Dyn . represented fowling birds. It takes places in a papyrus thicket. The top of the thick ends in three rows of above which birds are flying, a Hoopoe was identified with his beautiful color, it is the $2^{\text {nd }}$ one left (fig . 12).$^{37}$

Doc . 12: A scene from the Tomb of Hesi, Saqqara $6^{\text {th }}$ Dyn . represented a Hoopoe hovers over the papyrus thickets among the flying birds in the fishing scene, and another hoopoe fly's near the bird nests (fig . 13).$^{38}$

Doc . 13 : A scene from the tomb of Hesi depicted the fowling scene, the tomb owner is inside his boat with his families (his beloved wife and the eldest son), the Hoopoe flys over the thick papyrus (fig . 14) . ${ }^{39}$

Doc . 14: A scene from the Tomb of Hesi depicted his children in the second row, it presented different birds, the first one is a son called Khwy holds a hoopoe by the wings with his right hand and at the last is a girl holds also a hoopoe by the wings (fig. 15) ${ }^{40}$

\footnotetext{
${ }^{35}$ N.Kanawati ; M.Abder- Raziq, The Teti Cemetery at Saqqara, Titi cemi Vol. II (UK,1998), pl.35 , 59 , pl.69 , p. 59, 60 ; firth- Gunn, Rue de Tombeaux , , p. 15 , 16 .

${ }^{36}$ Kanawati, Tomb of (Neferseshmre and Seankhuiptah) , pl . 76, 69.

${ }^{37}$ N. Kanawati, M . Abder Raziq, The Teti Cemetery at Saqqara, The Tomb of Nikauisesi, Vol . VI (2000), p.17, pl. 50 (room I) .

${ }^{38}$ N.Kanawati, M.Abder Raziq, The Teti Cemetery, The Tomb of Hesi ,Vol V (1999) pl.18 .

${ }^{39}$ Ibid, pl. 54 .

${ }^{40}$ Ibid, pl. 15,53 .
} 
Doc . 15 : A destroyed fowling scene from the Tomb of Hesi depicted the tomb owner holds three birds in the middle of them is a hoopoe, also the children holds hoopoes (fig . 16- a).$^{41}$

Doc . 16 : A scene from the Tomb of Hesi, depicts the netting of birds, one hoopoe appeared in presumably a sycamore fig tree (fig . 16- b) .

Doc .17 : A scene from the Tomb No G. 6000 imy-r $6^{\text {th }}$ Dyn. depicted the triangular net has been outstretched from the crown of first tree which the birds preferred to perch on trees among them is a hoopoe. ${ }^{43}$

Doc . 18 : A harpooning hippopotamus scene from the tomb of Merruka Saqqara $6^{\text {th }}$ Dyn . depicted the Hoopoe nesting and protecting its baby or eggs (fig . 17).$^{44}$

Doc . 19 : A scene from the Tomb Chapel of Wattghthr the wife of Merruka and the daughter of king Teti represented her stands facing left wears a tight dress. In front of her stands her son, shown as naked child with a plait of hair, he holds a hoopoe in one hand and lotus flower in the other. The text above him reads $s 3 . s$ smsw mry.s mry- Teti- rn nfr mry " her eldest son, beloved of here, Meryteti, his beautiful name Mery (fig. 18). ${ }^{45}$

Doc . 20: A scene from the Tomb-chapel of the wife of Merruka depicted her son Mryteti holds the stem of the lotus flower and also holds a hoopoe by the wings (fig.19) ${ }^{46}$

Doc . 21 : A scene from the tomb of Queen Idout wife of Pepi I from Saqqara $6^{\text {th }}$ Dyn. depicted her standing on a boot in front of a

${ }^{41}$ Ibid , pl . 12, 54 .

${ }^{42}$ Ibid, pl . 56.

${ }^{43}$ Kent . R .Week, The Cemetery of The Mastaba, G. 6000 (Bosten ,1994), pl .48 = LD , II,53 .

${ }^{44}$ J. Vandier, Manuel d'Archeologie Egyptienne, Tom IV , Basreliefs et peitures (Paris , 1964) , fig . 434= Duell , Mrruka I , pl . 9 , 15 , 17 = E.Strowhal, life of Ancient Egypt (1996), p. 120 , No. 125 .

${ }^{45}$ N.Kanawati , M.Abder- Razig, Merruka and his Family, The Tomb of Waatetkhethar Part II (2008), p. 19 , pl. 3-4, 556, 59 .

${ }^{46}$ Ibid, pl.62, p. 27. 
block of birds in papyrus clump of the swamp scene, a hoopoe hovers and turns towards the rows with his curved beek (fig . 20) ${ }^{47}$ Doc . 22 : A fishing scene of the Tomb of Pepiankh from Meir $6^{\text {th }}$ Dyn. depicted the tomb owner and his family spearing the large fish , the scene also represented important pictures from the hoopoe's life, the $1^{\text {st }}$ a hoopoe fly's owner the swamp, the $2^{\text {nd }}$ another hoopoe protected its babies and the $3^{\text {rd }}$ one stands on his nest . (fig . 21). ${ }^{48}$ Doc . 23 : A fowling scene from the Tomb of Pepiankh at Meir depicted the tomb owner and his family, enjoyed fowling as a sport using a boomerang while the Hoopoe protected its nest and babies from a mangos, trying to pit him by its beek and another hoopoe is flying (fig . 22).

Doc . 24: A scene from the tomb of Pepiankh at Meir depicted a hoopoe hovers with his wings over a papyrus thickets (fig . 23)..$^{50}$

Doc . 25 : A scene of fishing and fowling from the tomb of Neferirtenef- Giza $6^{\text {th }}$ Dyn. represented the tomb owner and his family on a boat under his open legs his son stands, holds a hoopoe by the wings with his left hand (fig . 24) . ${ }^{51}$

Doc . 26 : A scene from the Mastaba of Kaemankh at Giza a $6^{\text {th }}$ Dyn. Old Kingdom, represented him and his families in the spearing fish act. The tomb owner stands on a boat and in front of him his son Wrkhw who holds a hoopoe by his wings . (fig . 25).$^{52}$

Doc . 27 : A scene from the tomb of Knounes at Zawit el Meitin, represented the tomb owner stands on a boat, uses his boomeranged to hunt the birds, which run over the papyrus thickets

\footnotetext{
${ }^{47}$ M . Macramallah, Le Mastaba d' Idout a Saqqara (1935), pl . VII ; J.Vandier, Manuel IV , fig. 154 .

${ }^{48}$ N .Kanawati, The Tomb and its significance in Ancient Egypt ( Cairo , 1999), p. 119, fig .30 .

${ }^{49}$ Ibid , p. 119 , fig . 32 ; J.Vandier Manuel IV , fig . 155.

${ }^{50}$ J.Vandier, Manuel IV , fig . 419- XII .

${ }^{51}$ J.Vandier, Manuel IV , fig . 399- I, Van de Walle, The Tomb of Neferirtenef, pl . 9.

52 J.Vandier, Manuel IV, fig . 407/ XXV.
} 
in the swamp, also a hoopoe was represented hovered with its wings (fig . 26). ${ }^{53}$

Doc .28: A scene from the tomb of Akhet- khper- hr.n from Saqqara6th Dyn. depicted the netting of birds. A Hoopoe can be seen standing on a tree- branch (fig .27).$^{54}$

\section{II- Hoopoe in the Middle Kingdom}

Doc . 29 : A scene from the tomb- chapel of Khnum- Hotep at Beni Hassan - Tomb. No.3 $12^{\text {th }}$ Dyn. depicted the bird- trapping scenes . Beside the fowling and spearing fish in the Marshes, the birds perched and fluted on a acacia tree, also a hoopoe can be seen standing in the lower branch of the tree (fig .28).$^{55}$

Doc . 30:A fowling and spearing fish scenes from the tomb of Sinbi from Meir $12^{\text {th }}$ Dyn. represented the tomb owner standing which his wife on a boat using the boomerang to catch birds.A hoopoe was depicted infront of him on a papyrus swamp.(fig . 29). ${ }^{56}$

\section{III- Hoopoe in the New kingdom :}

Examples of fishing and fowling scenes continued into the New Kingdom as an evidence from Theban Tomb, it shows the hoopoes in the swamp. ${ }^{57}$

Doc . 31 : A scene from the tomb of Intef TT $155.18^{\text {th }}$ Dyn. , shows the tomb owner throw stick to catch the birds, hoopoe can be seen flying over the swamp (fig . 30), and another hoopoe flied over the thickets in the scene of hunting a hippopotami (fig . 31) ${ }^{58}$ Doc . 32 : Another scene from the tomb of Intef TT.155, represented the papyrus thicket the hoopoe appeared with his

\footnotetext{
${ }^{53}$ J.Vandier, Manuel IV , fig . 408/ XXX .

${ }^{54}$ M . E . MATBE, NCTOPN- R NCKYCCTBA, PEBHEFO Boctoka, Tom I (1941), fig . 20 , p. 50 .

${ }^{55}$ P.E.Newberry , Beni Hassan, I , (1889), pls. XXXII- XXXIV ; W.S.Smith , The Art and Architecture of Ancient Egypt (1990), p. 201 , fig . 198 .

${ }^{56}$ J.Vandier, Manuel IV , fig . 227 ; A.Blackman, Meir I , pl. II ; II , pl. XV-II ; Smith , Art and Architecture (1990) , p. 203 , fig . 190 .

${ }^{57}$ S.Smith, Ibid , p. 285 ; E . Strouhal, Life of the Ancient Egypt (1996), 18/ No.113,166/ No . 183 ; D.J.Brewer, R.F.Friedman , Fish and Fishing in Ancient Egypt (1989) , p. 30 , fig . 2.15.

${ }^{58}$ J.Vandier, Manuel IV , fig . 430/ XXII .
} 
beautiful coolers hovered with his wigs, its tail was depicted different from the old and the middle kingdoms . (fig . 32) . ${ }^{5}$

Doc.33:A scene from the tomb of Dhwty-ms TT.32,18 Dyn.,represented the tomb owner with his family threw the Boomeranged in the fowling scene.A hoopoe stands on a papyrus in pace(fig . 33). ${ }^{60}$

Doc . 34 : A Scene from the tomb of Nefer- Hotep TT. $4918^{\text {th }}$ Dyn. , represented the tomb owner standing on a boat in fowling scene, a hoopoe appears flying above the papyrus clumps (fig . 34).$^{61}$ This scene Now is in the Louver Museum . (fig . 35) . ${ }^{62}$

Doc . 35 : A Scene from the Louvre Museum stela c. 18 , represented the spearing fish and fowling scenes, also the hoopoe fly's on the papyri swamp (fig . 36).$^{63}$

\section{IV-The Hoopoe in the Late and Greco-Roman Periods:}

The scenes of fowling and spearing fish continues in These Periods but the hoopoe disappeared from that scenes ${ }^{64}$ because of the funerary ideas which give the scenes its religious targets . There is an important seen in the Greco- Roman period depicted the personification of the Egyptian territories which was associated with the goddess Sekht, where the emblem of the Nome it refers to the Hierographic sign d.was represented with a hoopoe perched on his nest (fig . 37) .

\section{V-Conclusion :}

In a country which literally lived on the banks of the river with its aquatic life extended the marshlands in the north, the hoopoe was represented in the Old and Middle Tombs. In the New

\footnotetext{
${ }^{59}$ L.Manniche, The Tombs of the Nobles at Luxor (1989), 36 , fig . 3 .

${ }^{60}$ J.Vandier, Manuel IV , fig . 426/ XV .

${ }^{61}$ J.Vandier, Manuel IV, fig . 429/ XXI .

62 J.Vandier, Les Antiqueties Egyptienne au Musee du Louvre (1973) , pl.XVIII , p. 134 ; Patrik, F.Houlihan, Animal World, fig . 95.

${ }^{63}$ J.Vandier, Manuel IV , fig . 420 , p. 790 .

${ }^{64}$ The Bulletin of the Cleveland Museum of Art, Vol. LII (No.8), October (1956),p.104, fig . 3 .

${ }^{65}$ E.Drioton, G.Posener, J.Vandier, Tod I, Les Inscription du Temple ptolemaique et Romain , la sall hypostyle Texts No.1-172, (Le Cairo, IFAO, 1980), 108 .
} 
Kingdom the hoopoe is disappeared from many scenes of fishing and fowling that because of the Nobles had practiced their act of fishing and fowling in the Fayoum distract, not the marshland of the North ${ }^{66}$. It was many at Saqqara Tombs (fig . 1-20, 27), also depicted little on Giza (figs . 24, 25), Meir (figs . 21- 23, 29), Zawit el Maition (fig . 26), Beni Hassan (fig . 28) and Thebes in figs (30-36) .

Children of both sexes preferred to clutch a colorful pert Hoopoe as seen in (figs . 1, 2, 7, 15, 18, 19) and in the hand of tomb owner (16- a , 5).The scenes also depicted the hoopoe stands on a papyrus in figs . $6,3,39,34$., the hoopoe fly's in (figs . 3,5 , $6,8,9,12,13,14,20,23,25,26,30,31,32)$, the hoopoe perched on his nest in (figs . 3, 11, 17 and the hoopoe defended his eggs in ( fig . 22), also the hoopoe stands on the acacias tree in (figs . 4, 27, 28).

The artist painted the hoopoe with his natural color as seen trace pale red on bady, white, yellow and black tail detail . ${ }^{67}$

\footnotetext{
${ }^{66}$ W.Deker, Sports and Games, (1992), p. 160.
}

${ }^{67}$ Kanawati, The Tomb of Neferseshemre, p . 66. 


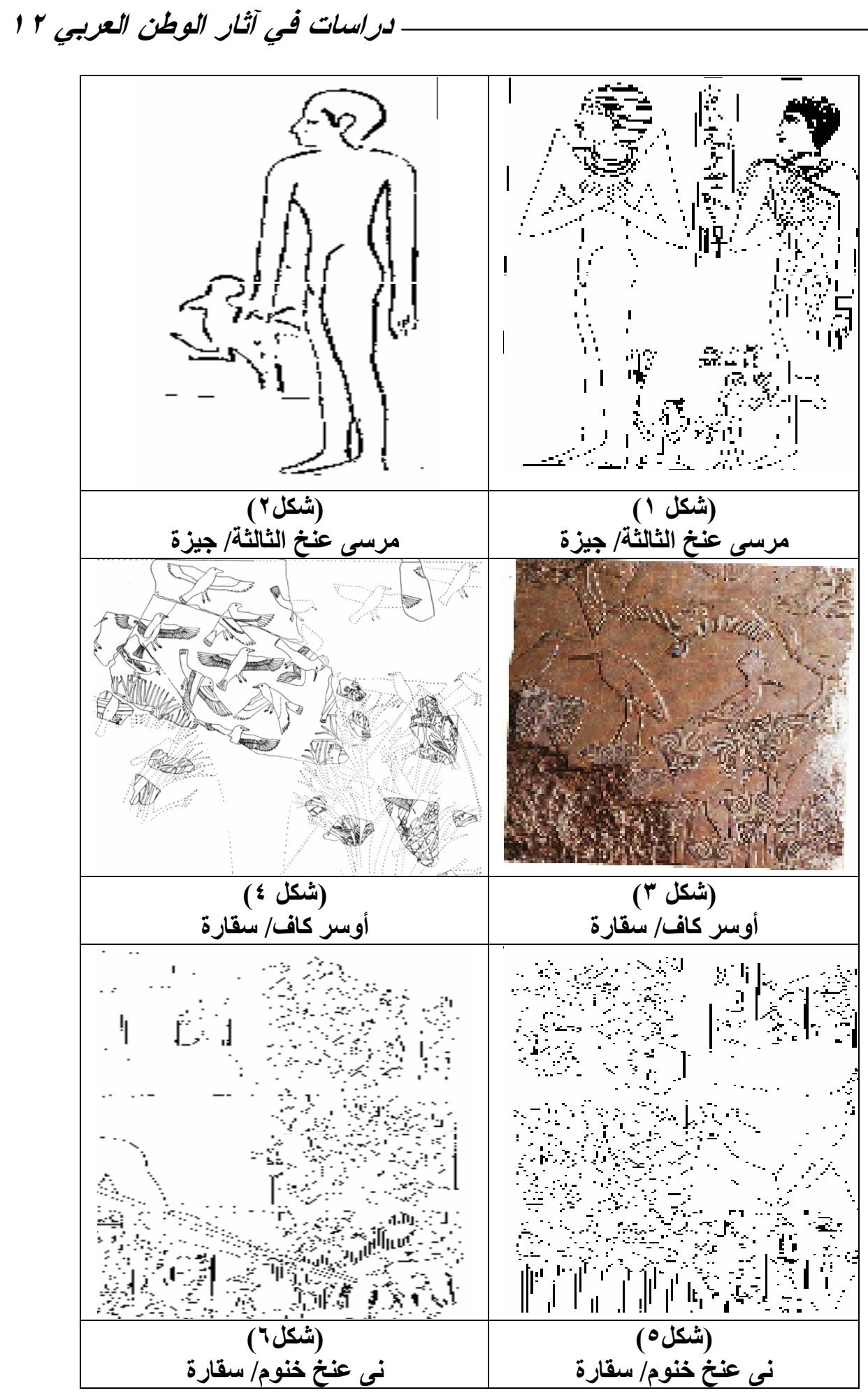




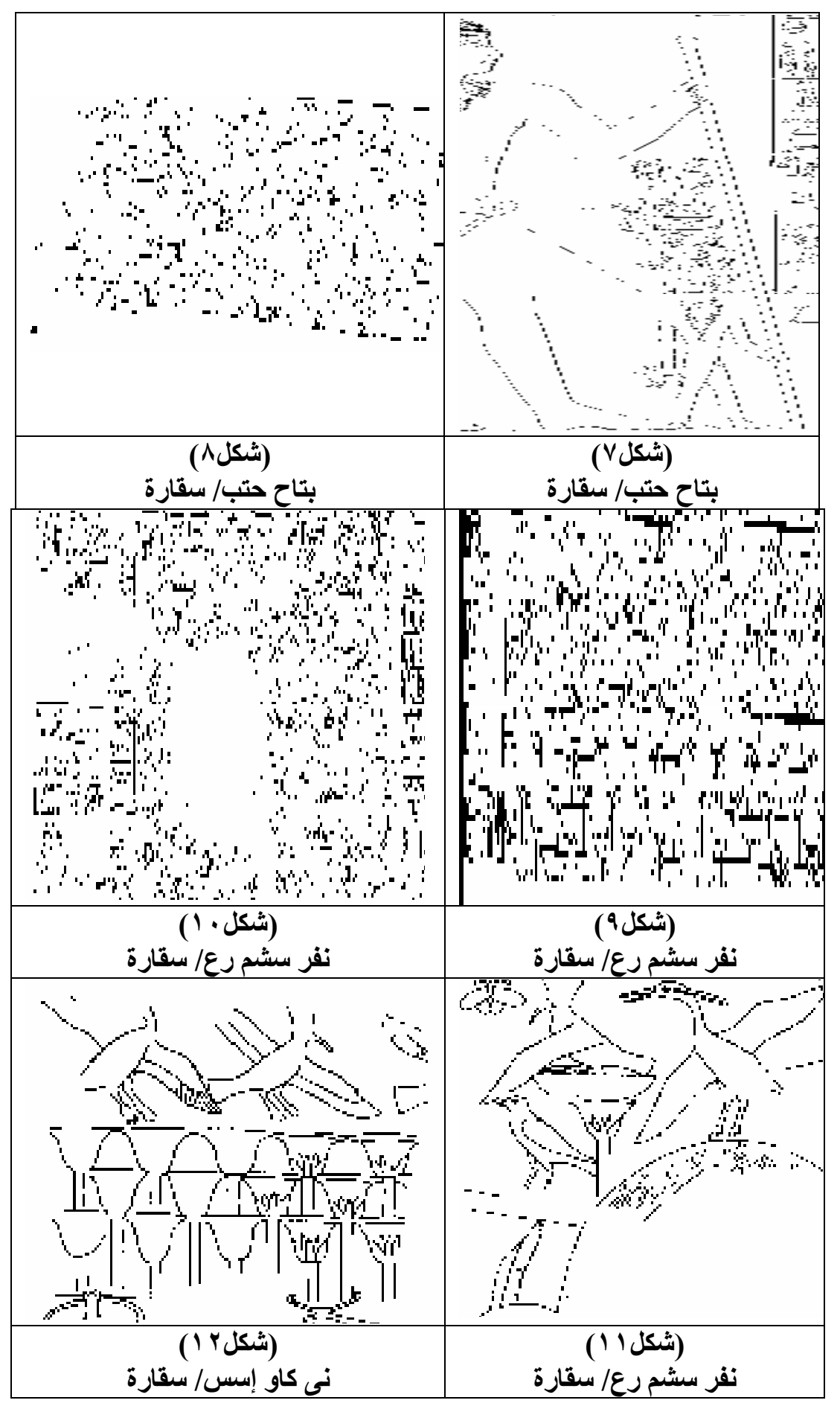




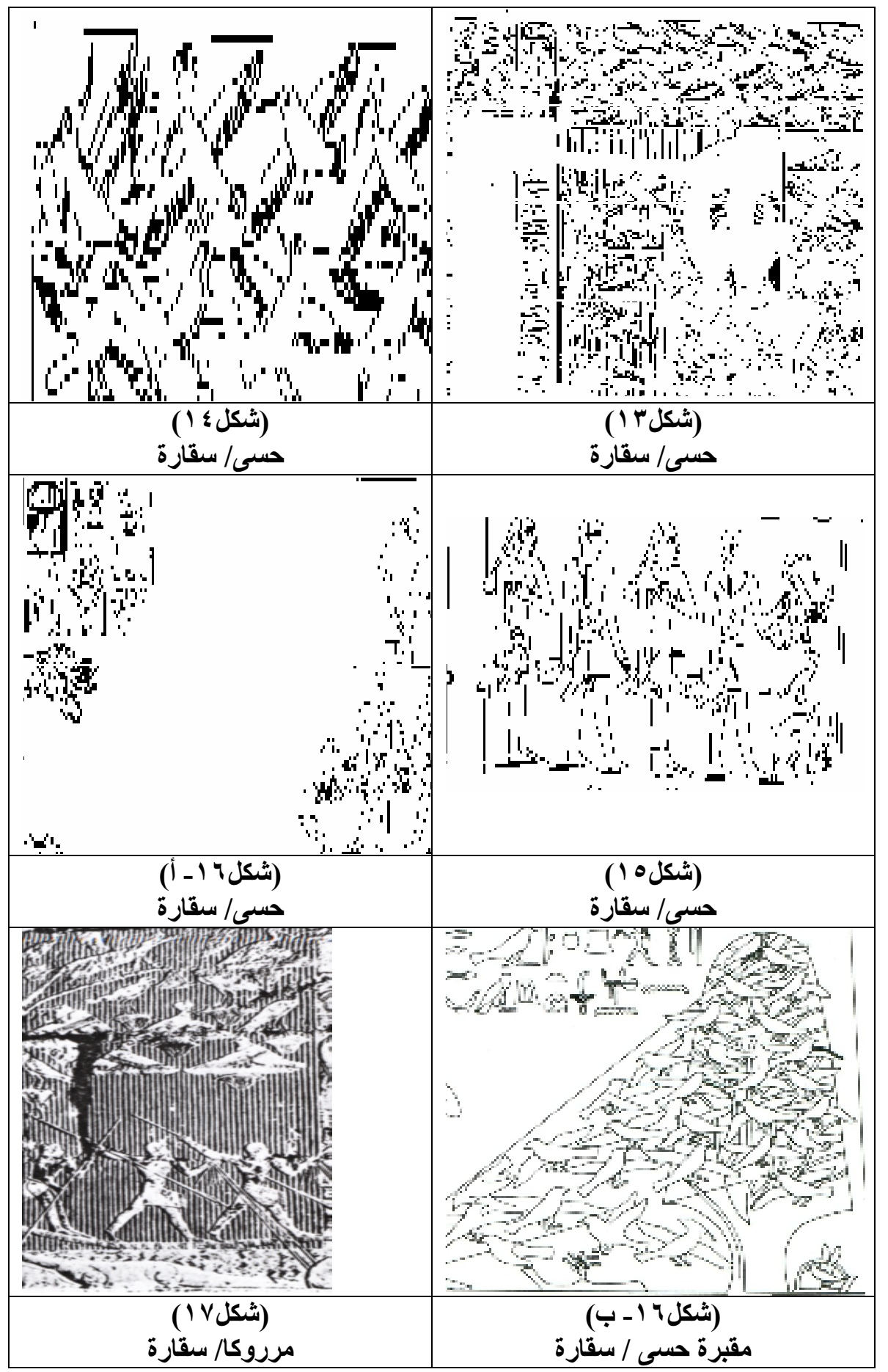


دراسات في آثار الوطن العربي ب 1

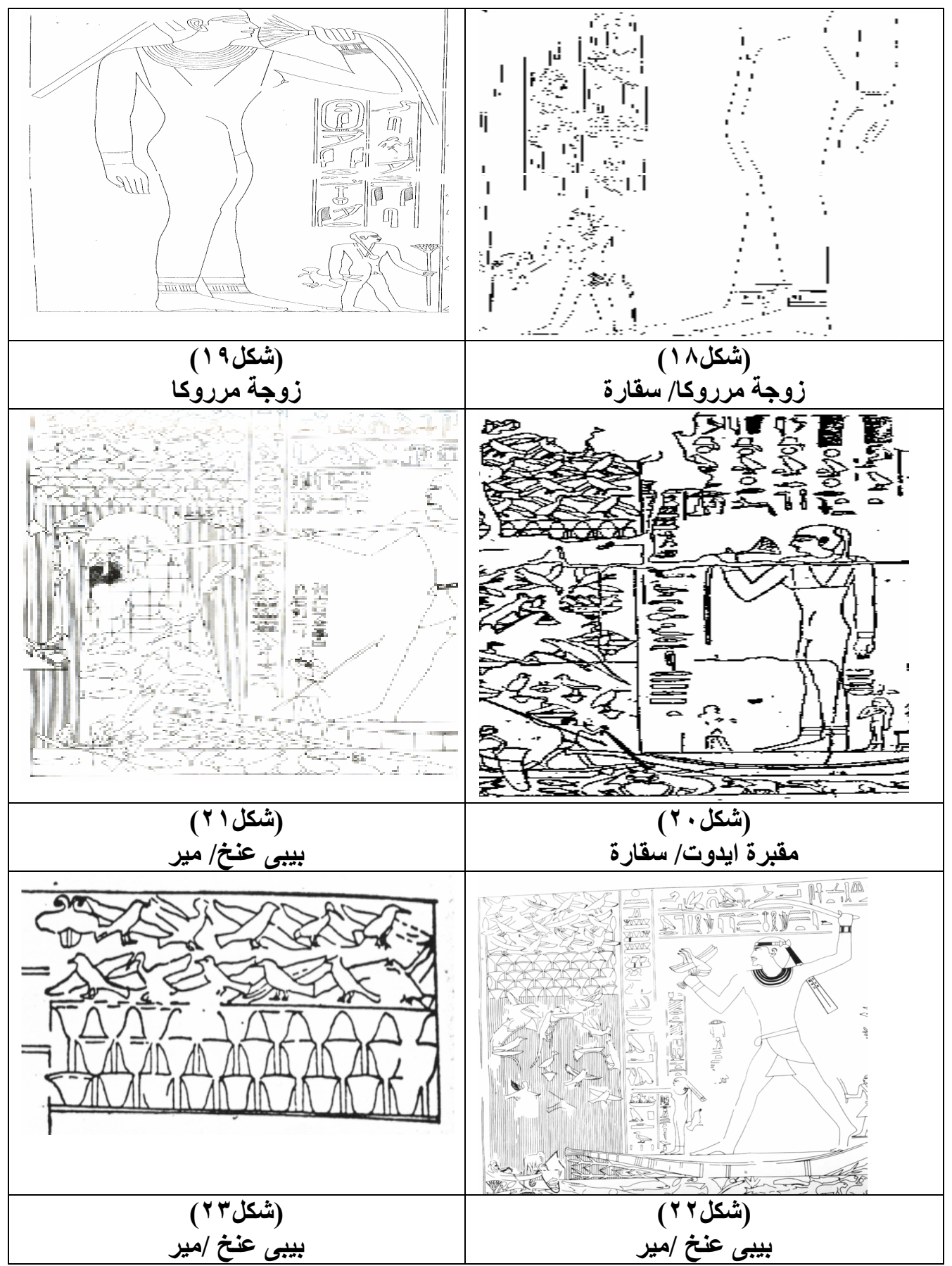


دراسات في آثار الوطن العربي ب 1

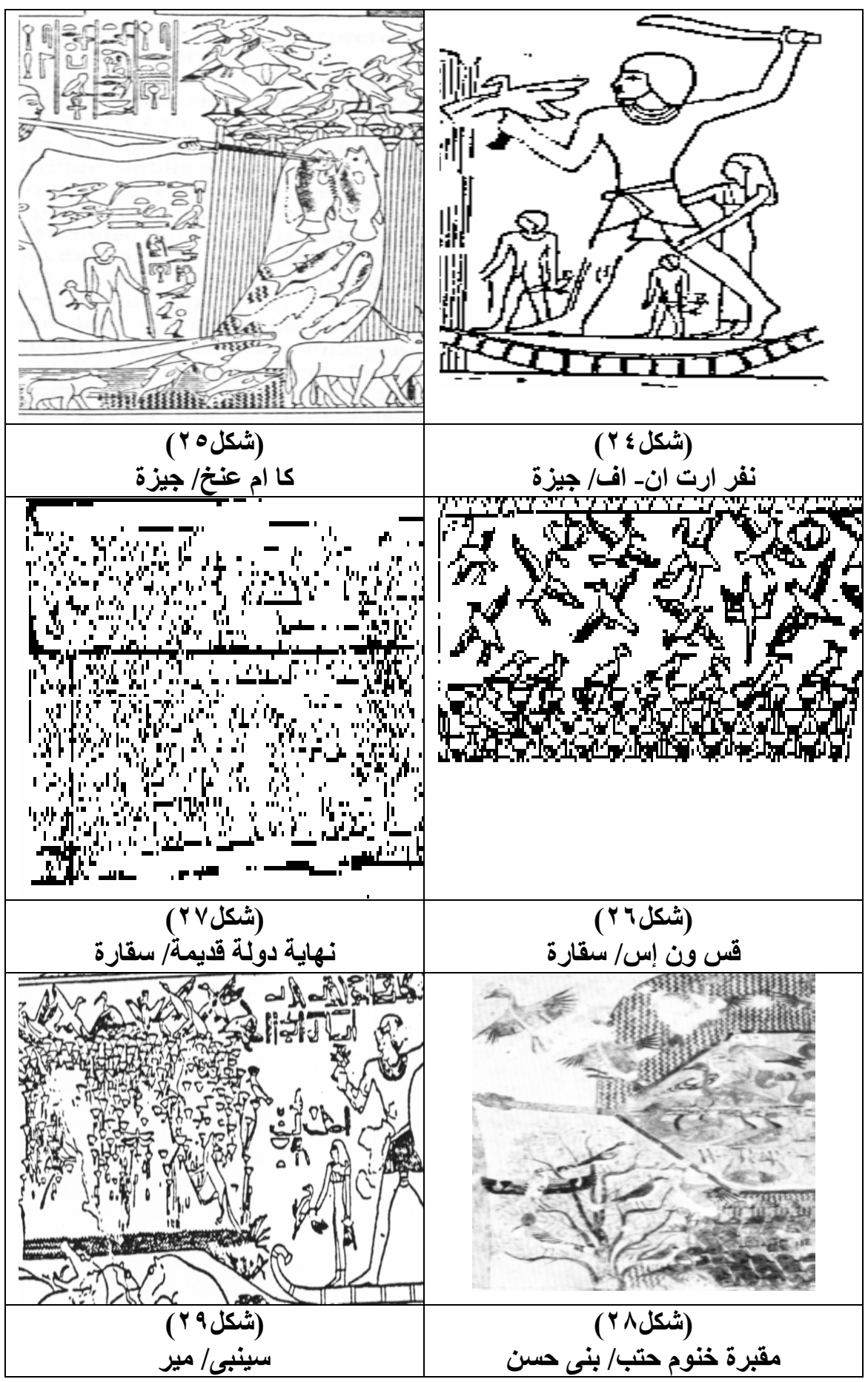


دراسات في آثار الوطن العربي ب 1

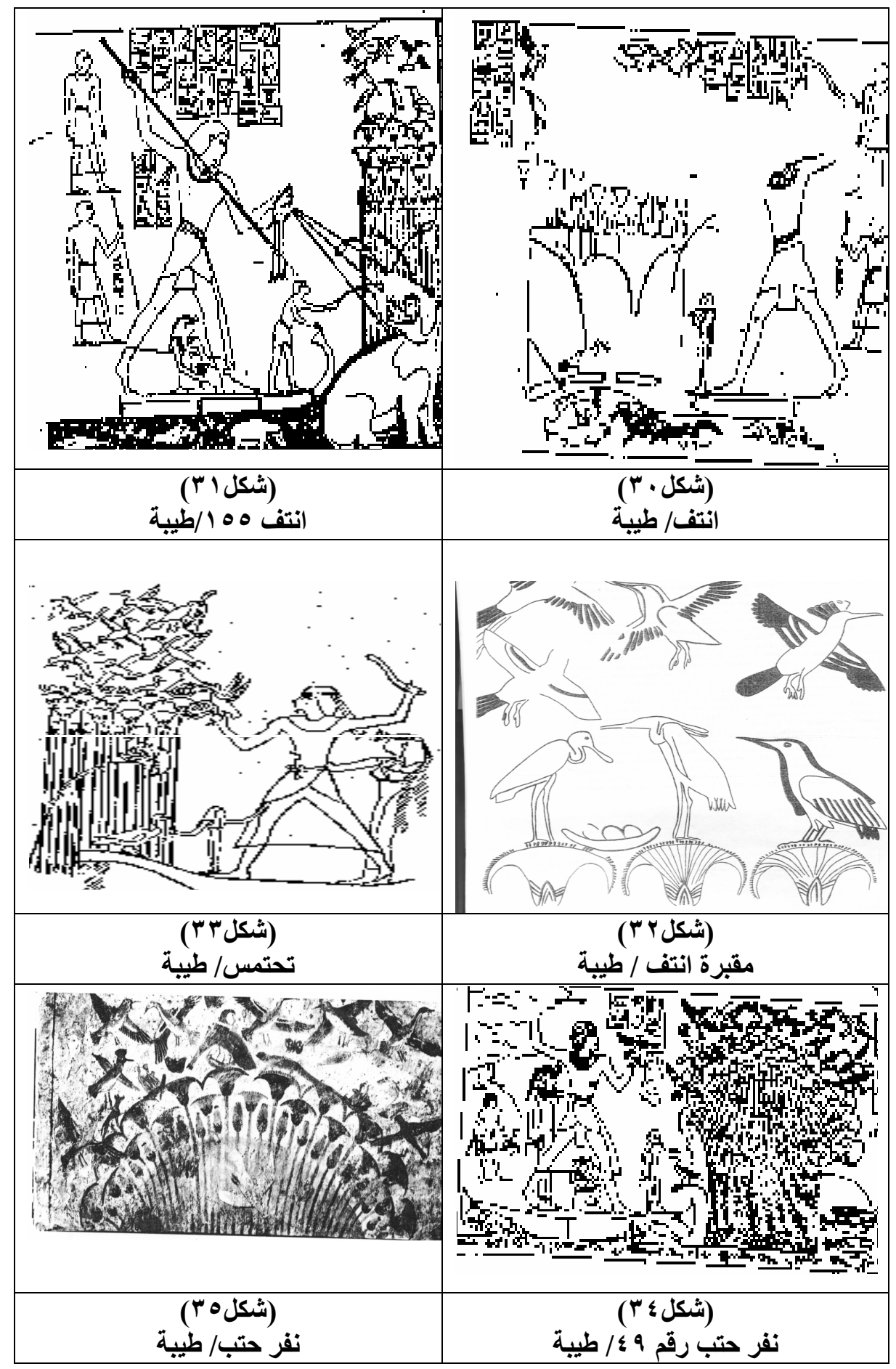


دراسات في آثار الوطن العربي r 1

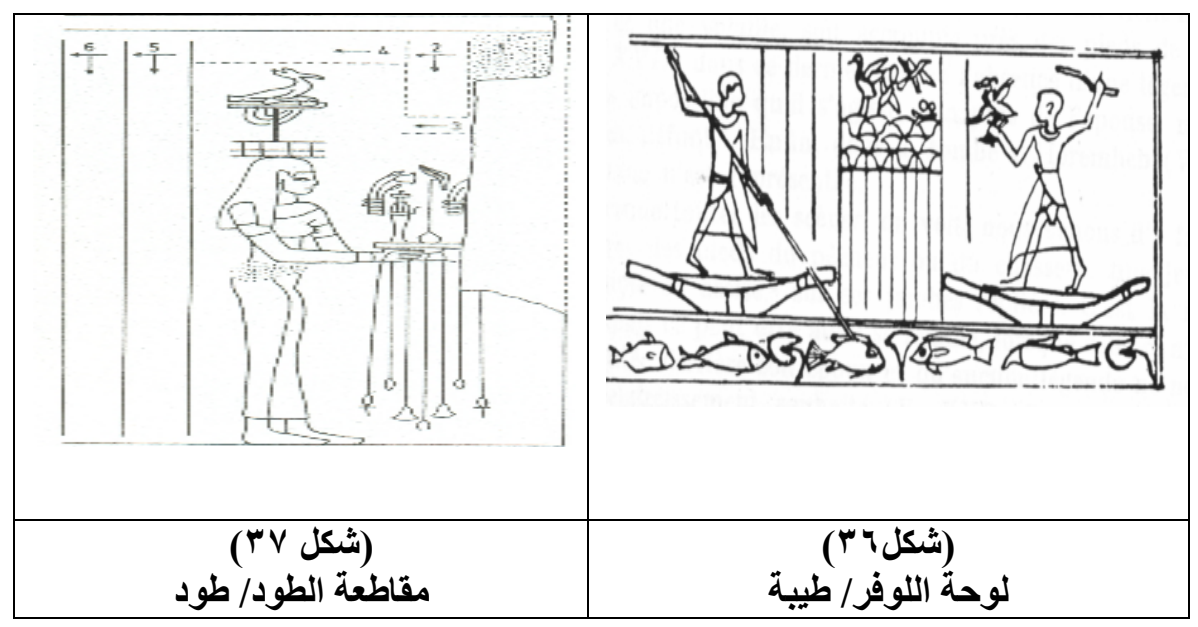




\section{Reference :}

1 - Patrick . F. Haulihan, The Animal World of The Pharaohs (Cairo, 1996) , 134 ; P.StrauB, “Vogel”, LA VI (1986) , 1046 ; Springerlinkmetapress.com . proceeding plant sciences vol.68, (1969), Amatory of the feeding AppA- ratus of hoopoe ;

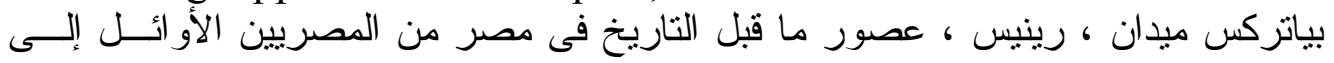

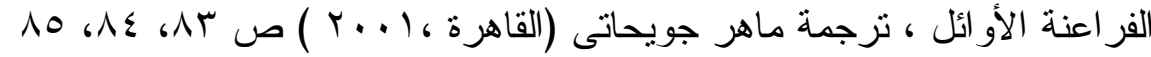

¿- W. M. F. Petrie, Corpus of Prehistoric Pottery and Palettes , BSAE (London , 1921) , pl.LIIL , 20 ; J.Vandier , Manuel d'Archeologie Egyptienne, Le époques de formation ( Paris , 1952) , 306 , 352 ; Petrie Corpus of Prehistoric Pottery , pl. XXXV- D. 50- 66 ;

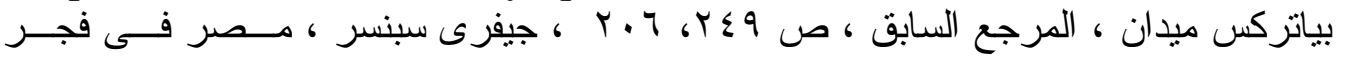

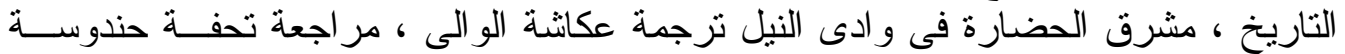

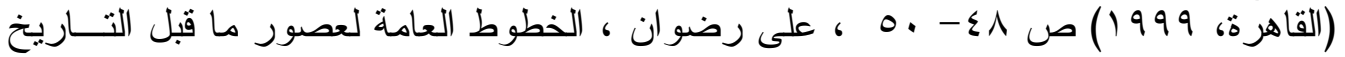

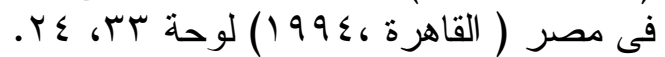

3 - W.F.Petrie , J.Qwible , Naqada and Ballas ,( London , 1895) , p1.LXIII

4- M.Elweshahy, Flint in The form of Animals in Prehistoric Egypt, Association of Arab Universities For Tourism and Hospitality, Ismailia, 20071 , p. 87 , figs. 32- 38 .

5 - B.Bruun, Common Birds of Egypt (Cairo , 1985) , 2 , 20 .

6- B.Bruun, Ibid (1985) , 34 ; F.Houlihan, Ibid (1996) , 112- 139) .

7- P.F.Haulihan, Animal World, p. 112.

8 - A.Gardiner, Egyptian Grammer (Oxford , 1973) , G.38 , 39 , 40 , 41 ; LD, III, 56-A .

9- B.Bruun, Common Birds , p. 34 , (4 : 22) , pl. 10 ; Gardiner , Egyptian Grammar, p. 469 .

${ }^{10}$ - Wb , VI , 553, 554 .

11- R. O. Faulkner, The Ancient Egyptian Pyramid Texts (2007), p. 37 , Utterance 241, 246 .

12 - Wb, V, 554/4.

$13-\mathrm{Wb}, \mathrm{V}, 554 / 18$.

$14-\mathrm{Wb}, \mathrm{V}, 554$, gr .

15- W.Wreszinski,The Text of Papyrus Ebers(Leipzig,1913),47(246),93 (276) ; 


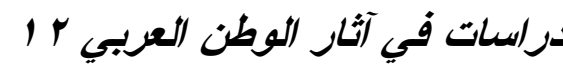

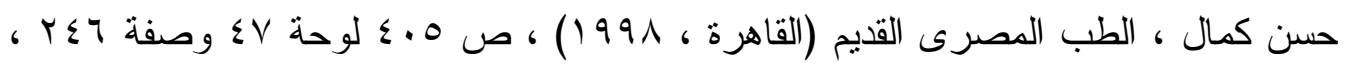

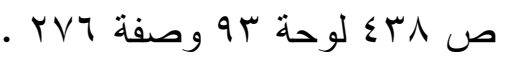

16 - F. L.Griffith , Hieratic papyri from Kahun \& Gurab,(1898),(511),(23-11) .

17- Papyrus of Westcar , 11,3 .

${ }^{18}$-Valeurs phonetiques des signes Hieroglyphiques d' Epoque GrecoRomaine (Montpellier, 1988), 343/1401, p. 87 .

19 - Ibid , 845/1402, p. 87 ; Wb , V , 561 .

${ }^{20}-\mathrm{Wb}, \mathrm{V}, 553$.

21- W.Decker , Sports and Games of Ancient Egypt, translated by A.Guttmans (1992), p. 158 . (figs. 123, 126 ; LD III , 56- A .

22 - W.Decker, Sports and Games , p. 159,160 .

${ }^{23}$ - O.R ,Faulkner, The Ancient Egyptian Coffin Texts spell 34 ; De Buck, The Egyptian Coffin Texts I (1935), 124 ; M.Elweshahy, Lakes

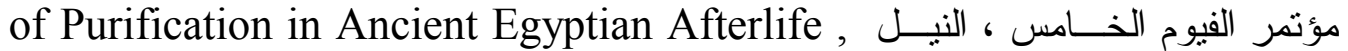

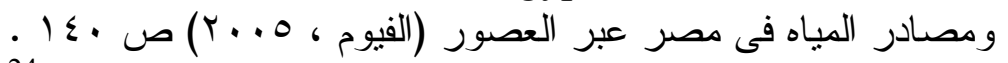

24 - Z- Hawas, The Treasures of The Pyramids (2010), p. 286- 327.

25 - D. Walfgang, Sports and Games , p. 160 .

${ }^{26}$-Holihan,The Animal World, p.112; E. Feucht , "Kind “ , LA III (1980), 427 ;

روز اليندم وجاك.ج.ياس ، الطفل المصرى القديم ، ترجمة أحمد زهير أمـين ، (القــاهرة ،

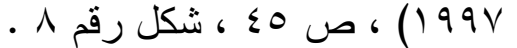

27 - A. Hassan, The Queens of The Fourth Dynasty (Cairo , 1997) , p. 20 ;

D.Dunhan, W. K. Simpson, The Mastaba of Queen Merey-Aankh III (Buston , 1974), pl. VII , p. 14 (main roon- w.w) .

28 - Ibid, pl. VII , p.14, fig .7.

29 - W.S.Smith , The Art and Archtecture of Ancient Egypt (1990), fig . 119 , p. 127 ; Z.Hawas, The Treasures of The Pyramids (Cairo , 2010), p. 237 ; J.P.Corteggiani , Egyptian Museum (1987) , No. 19 , p. 50 ; M.Saleh, H.Sourouzian, The Egyptian Museum (Cairo, 1987), No. 36 . ${ }^{30}$ - Smith, Art and Architecture, p. 127 , 128 , fig . 120 ; LD, II .55 .

${ }^{31}$ - A. M. Moussa, H. Altenmiller, Das Grab des Nianch Chnum und Chnumhotep (Mainz, 1977), Abb.6, SZ.4. (302) .

32 - Maussa, Altenmuller, Nianchchnum, Abb.5, SZ.4. (301) .

33 - N.de G.Davies, The Mastaba of Ptahhotep and Akhethotep at Saqqara ,Part II (London, 1901), pl.III 
34 - Davies, Ptahhotep, Part II , pl. IV .

${ }^{35}$ - N.Kanawati ; M.Abder- Raziq, The Teti Cemetery at Saqqara, Titi cemi Vol. II (UK,1998) , pl.35 , 59 , pl.69 , p. 59 , 60 ; firth- Gunn , Rue de Tombeaux , , p. 15,16 .

36- Kanawati, Tomb of (Neferseshmre and Seankhuiptah) , pl . 76, 69 .

${ }^{37}$ - N. Kanawati, M . Abder Raziq, The Teti Cemetery at Saqqara, The Tomb of Nikauisesi, Vol . VI (2000), p.17, pl. 50 (room I) .

${ }^{38}$ - N.Kanawati , M.Abder Raziq, The Teti Cemetery, The Tomb of Hesi ,Vol V (1999) pl.18 .

39 - Ibid, pl. 54 .

${ }^{40}$ - Ibid, pl. 15, 53 .

${ }^{41}$ - Ibid, pl . 12, 54 .

${ }^{42}$ - Ibid, pl . 56 .

${ }^{43}$ - Kent . R . Week, The Cemetery of The Mastaba , G . 6000 (Bosten ,1994), pl . $48=\mathrm{LD}, \mathrm{II}, 53$.

44. J. Vandier, Manuel d' Archeologie Egyptienne, Tom IV , Basreliefs et peitures (Paris , 1964), fig . 434= Duell, Mrruka I , pl . 9 , 15, $17=$ E.Strowhal , life of Ancient Egypt (1996) , p. 120 , No. 125.

${ }^{45}$ - N.Kanawati, M.Abder- Razig, Merruka and his Family, The Tomb of Waatetkhethar Part II ( 2008), p. 19, pl. 3-4 , 556 , 59 .

${ }^{46}$ - Ibid, pl.62, p. 27 .

47- M . Macramallah, Le Mastaba d' Idout a Saqqara (1935) , pl . VII ; J.Vandier, Manuel IV , fig . 154 .

${ }^{48}$ - N .Kanawati, The Tomb and its significance in Ancient Egypt ( Cairo , 1999), p. 119 , fig . 30 .

${ }^{49}$ - Ibid , p. 119, fig . 32 ; J.Vandier Manuel IV , fig . 155 .

${ }^{50}$ - J.Vandier, Manuel IV , fig . 419- XII .

51- J.Vandier, Manuel IV , fig . 399- I, Van de Walle, The Tomb of Neferirtenef, $\mathrm{pl} .9$.

52- J.Vandier, Manuel IV , fig . 407/ XXV .

53. J.Vandier, Manuel IV , fig . 408/ XXX .

54- M . E . MATBE, NCTOPN- R NCKYCCTBA, PEBHEFO Boctoka, Tom I (1941), fig . 20 , p. 50 .

55- P.E.Newberry , Beni Hassan , I , (1889), pls. XXXII- XXXIV ; W.S.Smith, The Art and Architecture of Ancient Egypt (1990) , p. 201 , fig. 198 . 


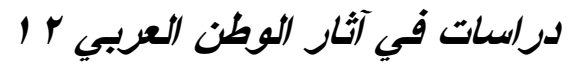

56- J.Vandier, Manuel IV , fig . 227 ; A.Blackman , Meir I , pl. II ; II , pl. XV-II ; Smith, Art and Architecture (1990), p. 203 , fig . 190 .

57- S.Smith , Ibid , p. 285 ; E . Strouhal, Life of the Ancient Egypt (1996) , 18/ No . 113 , 166 / No . 183 ; D.J.Brewer , R.F.Friedman , Fish and Fishing in Ancient Egypt (1989), p. 30 , fig . 2. 15 .

58 - J.Vandier, Manuel IV , fig . 430/ XXII .

59 - L.Manniche, The Tombs of the Nobles at Luxor (1989), 36 , fig . 3 .

${ }^{60}$ - J.Vandier, Manuel IV , fig . 426/ XV .

61 - J.Vandier, Manuel IV , fig . 429/ XXI .

${ }^{62}$ - J.Vandier, Les Antiqueties Egyptienne au Musee du Louvre (1973), pl.XVIII , p. 134 ; Patrik , F.Houlihan, Animal World, fig . 95 .

63 - J.Vandier, Manuel IV, fig . 420 , p. 790 .

${ }^{64}$ - The Bulletin of the Cleveland Museum of Art , Vol. LII (No.8), October (1956), p. 104 , fig . 3 .

65 - E.Drioton, G.Posener, J.Vandier , Tod I, Les Inscription du Temple ptolemaique et Romain, la sall hypostyle Texts No.1- 172, (Le Cairo , IFAO , 1980), 108 .

66- W.Deker, Sports and Games, (1992), p. 160 .

${ }^{67}$ - Kanawati, The Tomb of Neferseshemre , p . 66. 


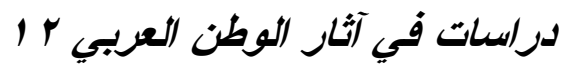 \\ الكهدهد فى مصر القديمة}

د.مفيدة حسن الوشاحي

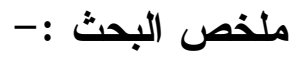

صورت المناظر في مصر القديمة كل أنواع الطيور التي تعيش في البيئة المــصرية

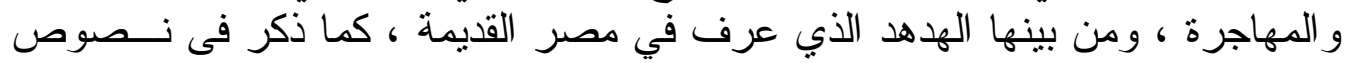

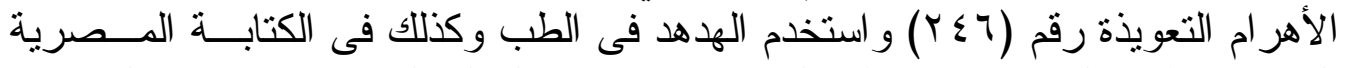

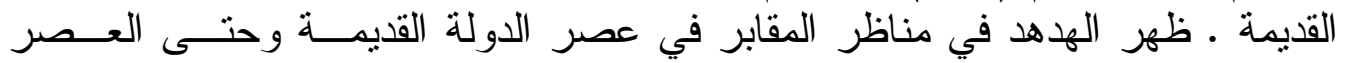

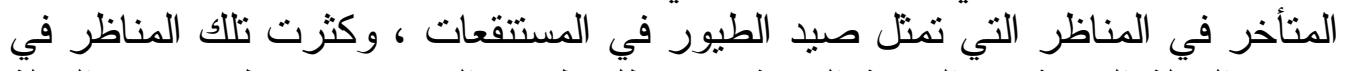

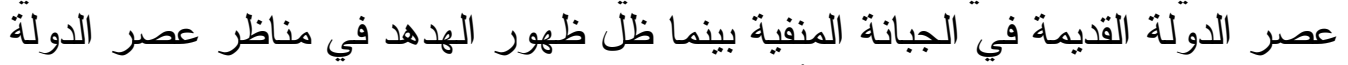

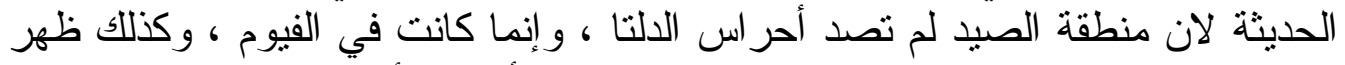

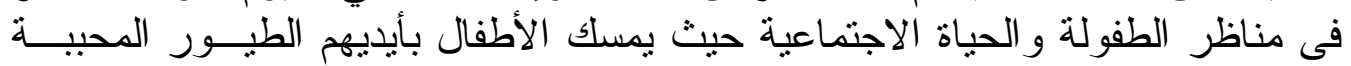
لايهم منت الهدهد 